Natural Hazards and Earth System Sciences (2004) 4: 599-613

SRef-ID: 1684-9981/nhess/2004-4-599

(C) European Geosciences Union 2004

\title{
The value of historical documents for hazard zone mapping
}

\author{
F. Barnikel \\ Dept. of Geo- and Environmental Sciences, Geography Sect., Univ. of Munich, Luisenstrasse 37, 80333 Munich, Germany
}

Received: 28 July 2004 - Revised: 30 September 2004 - Accepted: 11 October 2004 - Published: 13 October 2004

\begin{abstract}
The assessment of historical data of small mountain torrents in Alpine catchment areas has shown a significant difference between the results of a regular hazard zone mapping and a thorough historical analysis. The Gemsbach in the Ostrach valley near Hinterstein (Municipality of Hindelang, southern Bavaria/Germany) serves, among others, as an example. A "traditional" hazard zone for the Gemsbach has been mapped in the 1990s. The oldest event included in the analysis was the flood of 1954. But historical data collected and analysed by the HANG-project shows floodprone areas around the Gemsbach differing greatly in size and location from the one shown in the hazard zone maps. The inclusion of all data available for the Gemsbach area (15 events between 1671 and 1960 collected from four different archives) leads to a completely new picture of the regional hazardous activity and demands a re-structuring of the traditional way of hazard zone mapping.
\end{abstract}

\section{Rules for hazard zone mapping}

Local thunderstorms can trigger off extremely high peaks of run-off discharge within very short time in the relatively small catchment areas of mountain torrents in the Bavarian Alps. As a result, many torrents react very individually with either small scale flash floods or debris-flows which endanger the population and the infrastructure of the surrounding area. The majority of torrents has therefore been blocked since the late 19th century by the administrative offices for water management. Nevertheless, due to the decaying of older structures and the recent climatic development torrents still tend to threaten human lives and goods and many of them are, consequently, under constant monitoring. One additional way to mitigate natural hazards in the Alps is the development of hazard zone maps.

Correspondence to: F. Barnikel

(barnikel@geographie.uni-muenchen.de)
Several steps have to be made in order to gather sufficient information for a hazard zone map. Aulitzky (1996, 178) states that "already before the fieldwork the total consideration of the geological, hydrogeological, hydrological, orographic data and the characteristics of vegetation" is a necessary prerequisite. Additionally, data on land-use, climatic conditions, aerial pictures etc. have to be collected. Inspection in the field allows the inclusion of more recent features which may not be included in other data bases or written sources. Aulitzky especially mentions "silent witnesses" (Aulitzky, 1992), geomorphic and channel oriented marks in the field, which bear information on past events. The geomorphic features of the research area may, eventually, be mapped and process models can be established.

Furthermore (confer WLV, 1994), locals have to be interviewed about extent and severity of past events and historical documents should be included in the collection of data for the hazard zoning. Even if there are no compulsory regulations about which information to take in and which not, a rudimentary historical analysis is considered vital for hazard zoning. But as Wagner and Suda have recently found out $(2004,286)$, "the knowledge about floods, land slides and debris flows is mostly poor" among the local population. In the Hindelang area, only about $10 \%$ of the interviewed people were able to remember events which took place more than 40 years ago (Wagner and Suda 2004, 289). Many people, on top of that, were only able to approximately date the event and give information about extent and severity. One has to conclude that the questioning of locals may be an additional source of information, but with strictly limited value. Especially with the sometimes long intervals of hazardous activity in the small catchment areas of mountain torrents short series of data are hardly acceptable. Thus, the information gathered from the local population can only account for a few decades and must be supported by more concrete data from other sources like the historical analysis of written documents, as is for example carried out by the HANG-project (see Sect. 2.2). 


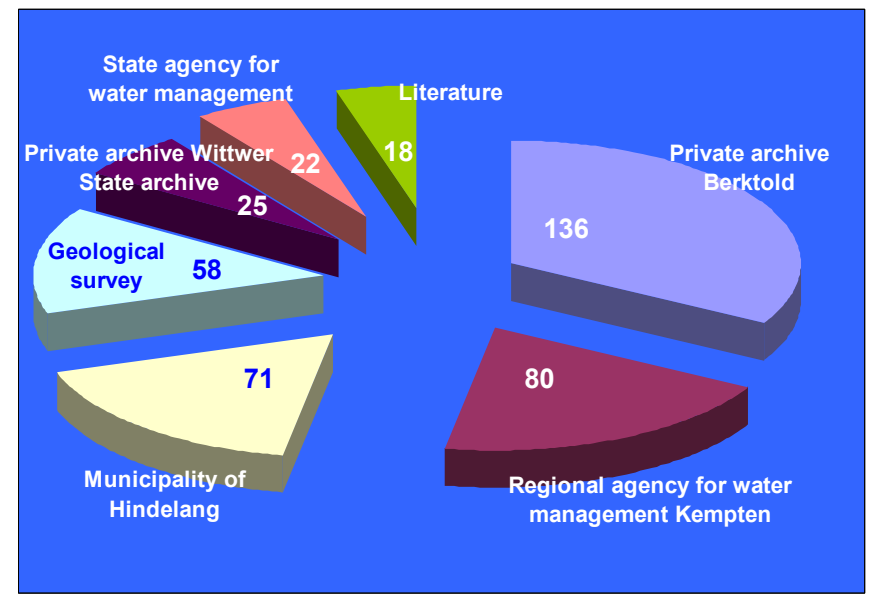

Fig. 1. Distribution of the total number of events for the different relevant archives.

\section{Historical data and hazard zoning}

\subsection{The value of historical data in general}

When dealing with historical data one has generally to bear in mind that documents may differ greatly in terms of age, quality and relevance. Flood frequency analyses for example become much more reliable when they include historical information in certain intervals (Stedinger and Cohn, 1986; Gees, 1997). Naulet et al. (2001), too, regard the cooperation between historians and geoscientists (as is the case with the HANG-project, Sect. 2.2) as very valuable when dealing with especially extreme events. The results of the SPHERE project in France and Spain show how successful this kind of cooperation can prove (Benito and Thorndycraft, 2004). One can differentiate between censored data, where the peak of an event is known, and binominal data, which describes the transgression of a threshold alone (e.g. the fact that something was damaged - Stedinger and Cohn, 1986). The archives and documents analysed by HANG show both kinds of data, the majority of which is binominal data.

The evaluation of concrete events raises some questions. Fliri (1998) points out that our knowledge on extreme events before the 20th century is basically based on qualitative pieces of information in general, which are usually not evaluated critically. The subjective character of some of the information needs critical assessment concerning its trustworthiness (Pfister, 1999). "It is [on the other hand] one of the peculiarities of historical sources that they react very sensitive towards extreme events" (Pfister and Hächler 1991, 143). Wang and Zhang (1988) in general think that historical anthropogenic data is more direct, clear and in most cases also more reliable than proxy data (pollen, tree rings etc.), Baron (1995) even thinks it's more precise than early instrumental data.

Sources for historical data on natural hazards can be multifarious. Deutsch and Pörtge (2002) have worked with in-

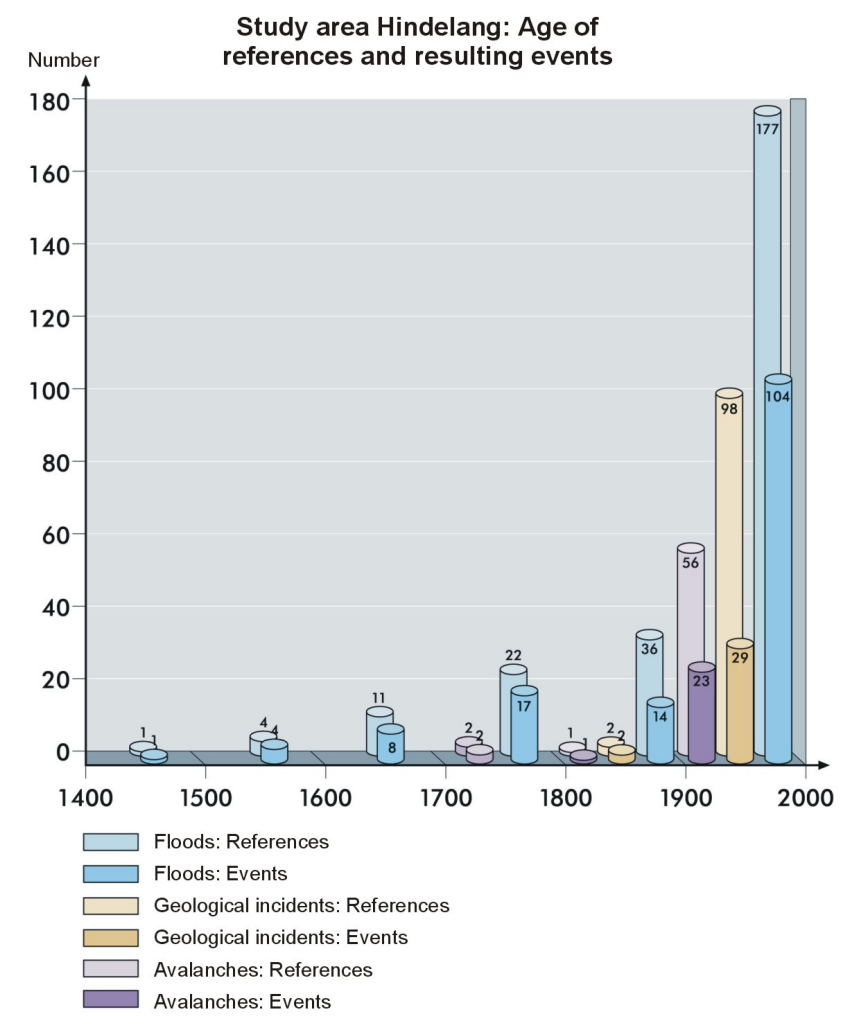

Fig. 2. Age of the references and the resulting events.

scriptions on stone pillars and buildings describing historical water levels of nearby rivers. Similarly ancient documents include paintings (cf. Pfister, 1999), texts from rogation ceremonies (Martín-Vide and Barriendos, 1995), legends or sagas. More continuity with regards to recurring hazards like floods can be found in annals, diaries and measuring journals. Cadastral maps and administrative files from usually more recent times add enormously to the number of documents available. Sometimes letters or other private documents may be applicable, as are postcards, recent drawings or the bookkeeping of great estates. The documents or sources are used to reconstruct climate (e.g. Pfister, 1999; Glaser, 2001), analyse floods (e.g. Benito and Thorndycraft, 2004), geomorphic hazards or earthquakes (e.g. Glade et al., 2001), and avalanches (e.g. Ammann et al., 1997; Barnikel and Copien, 2004), to name the most important fields.

The quality of information from historical documents depends greatly on various factors. First there is the number of archives with information on a certain event. The more archives yielding data on the event, the better (Fig. 1). Often graver events have found entry in different kinds of archives. Municipal archives for example may account for information on the financial aspect of the damage done, while private archives tend to deal with subjective impressions, for example personal damage or detailed descriptions of local damage. The different points of view concerning one specific event may contribute to a more differentiated view of the whole event (Fig. 2). A second aspect is the authenticity 


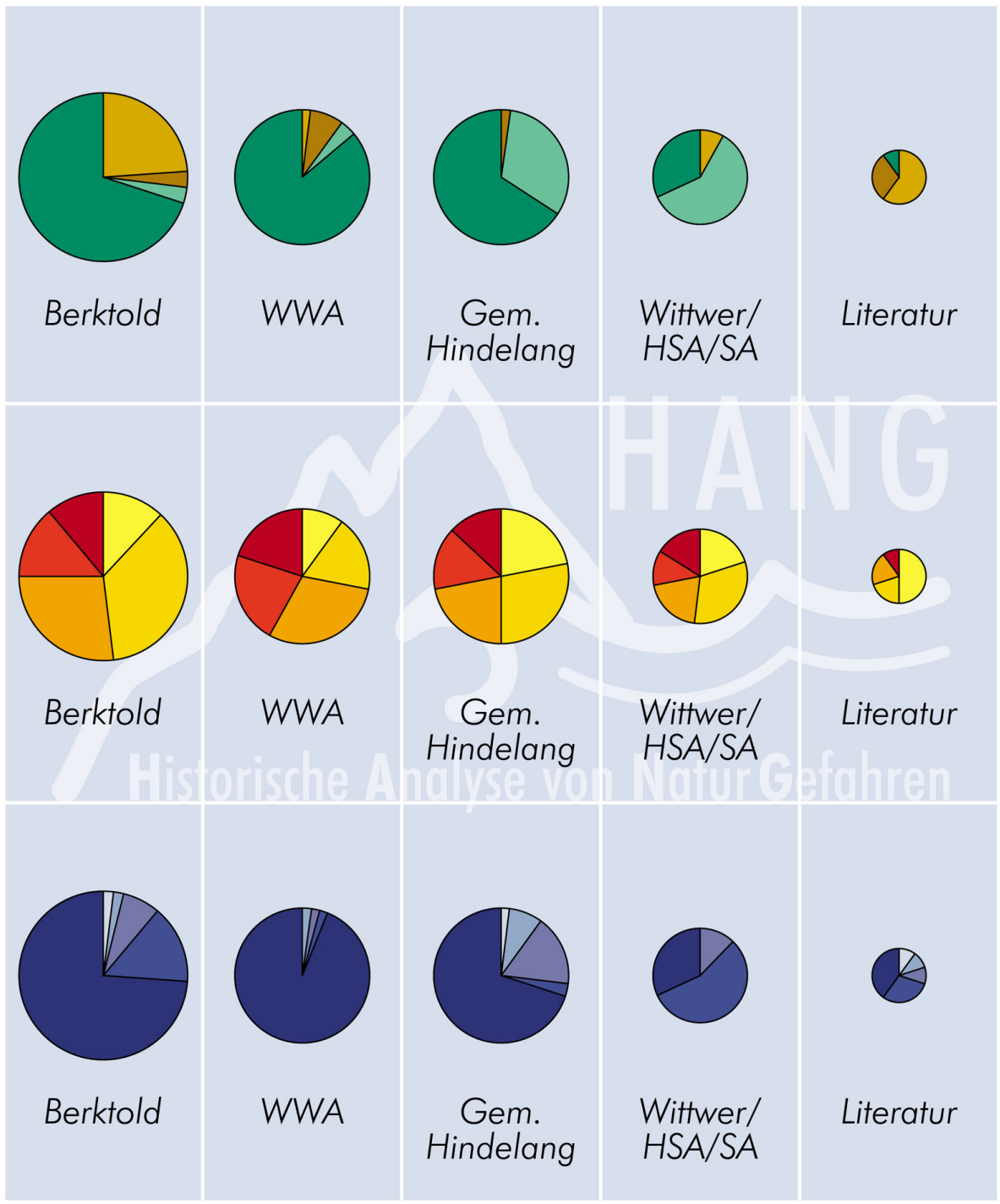

Fig. 3. Flood events: authenticity, quality, age of references (Berktold = private archive of Mr. Berktold, WWA = Local Hydrological Office in Kempten, Gem. Hindelang = Municipality of Hindelang, Wittwer/HSA/SA = private archive of Mr. Wittwer plus data from the State Archives of Bavaria, Literatur = data from literature); Key to Figs. 3-5: The sizes of the circles show the relative importance of the circle in question for the total number of units. The bigger the circle, the more references came from the respective archive. Authenticity (green/brown): Green segments show contemporary references to certain events, dark green from the 20th century, light green from pre 1900. Brown segments show younger references from years after the event, dark brown for references from the 20th century, light brown from pre 1900. Quality (red/yellow): The darker the colour, the better the quality of the reference. Age of references: the darkest shade of blue represents the 20th century, lighter shades represent earlier centuries.

of the documents. The overall majority of documents should be contemporary, whereas younger documents, written years after the event had taken place, may only be included as an exception. It is usually only the contemporary sources that offer an unbiased view of the event, later additions could lead to a distorted picture. The most important aspect, though, is the quality of information itself. Some documents only mention an event, others give a detailed description. Only documents with sufficient information enable further analyses (Figs. 3-5).

\subsection{Historical data and the HANG-project}

The project HANG (Historische Analyse von NaturGefahren/Historical analysis of natural hazards) at the Universities of Munich and Eichstätt deals with the historical analysis of natural hazards in the Alps (for an in-depth analysis see Barnikel, 2004). The research work in this case focuses on hydrological features like floods, debris-flows, geomorphic/geological events (like rock falls and land slides) and snow avalanches. HANG works with written documents, maps and photographs on past hazardous events. The relevant public and private archives of the study areas are 


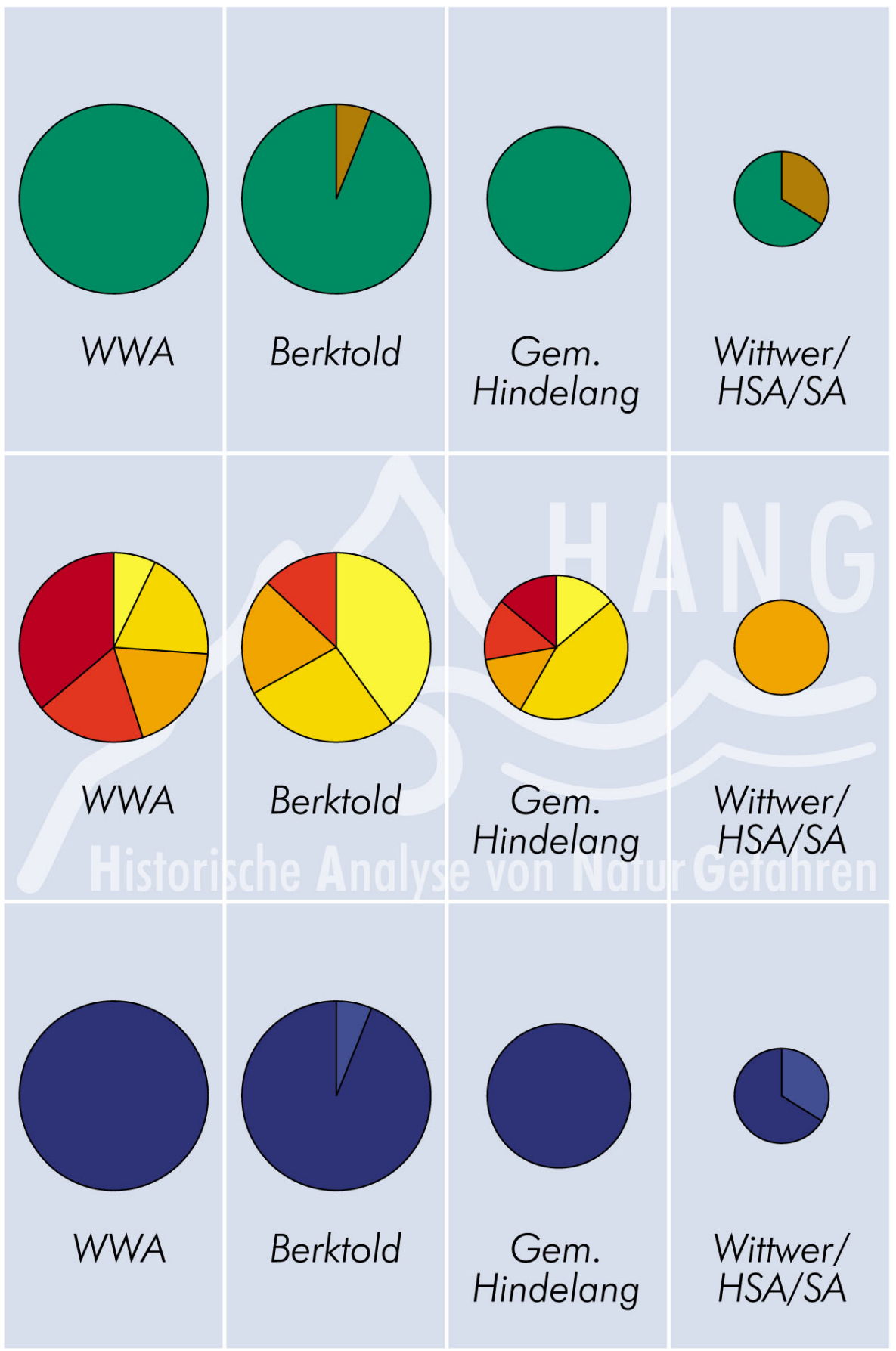

Fig. 4. Geomorphic events: authenticity, quality, age of references (key: see Fig. 3).

thoroughly scrutinized (like the administrative offices for hydrology and geology, local hydrological offices, archives of municipal authorities, forestry archives and private collections like chronicles or newspaper archives).

Climate data and palaeoflood data in general derived from historical documents or proxy data have been collected in many parts of the world especially in the past decades. The data has mostly been collected for larger areas or fluvial systems. One result is a comparatively high density of infor- mation back to the Middle Ages, in some areas of the former Roman Empire even longer. For a more detailed and concrete point of view, however, for example the establishing of hazard zoning, this data, if based only on historical documents, is only of limited value. The HANG project therefore concentrates on a local analysis of the hazard situation in one or more closely connected communities. This study is the first of its kind, just focussing on a clearly defined area and the natural hazards there, regardless of the kind of event, whether 


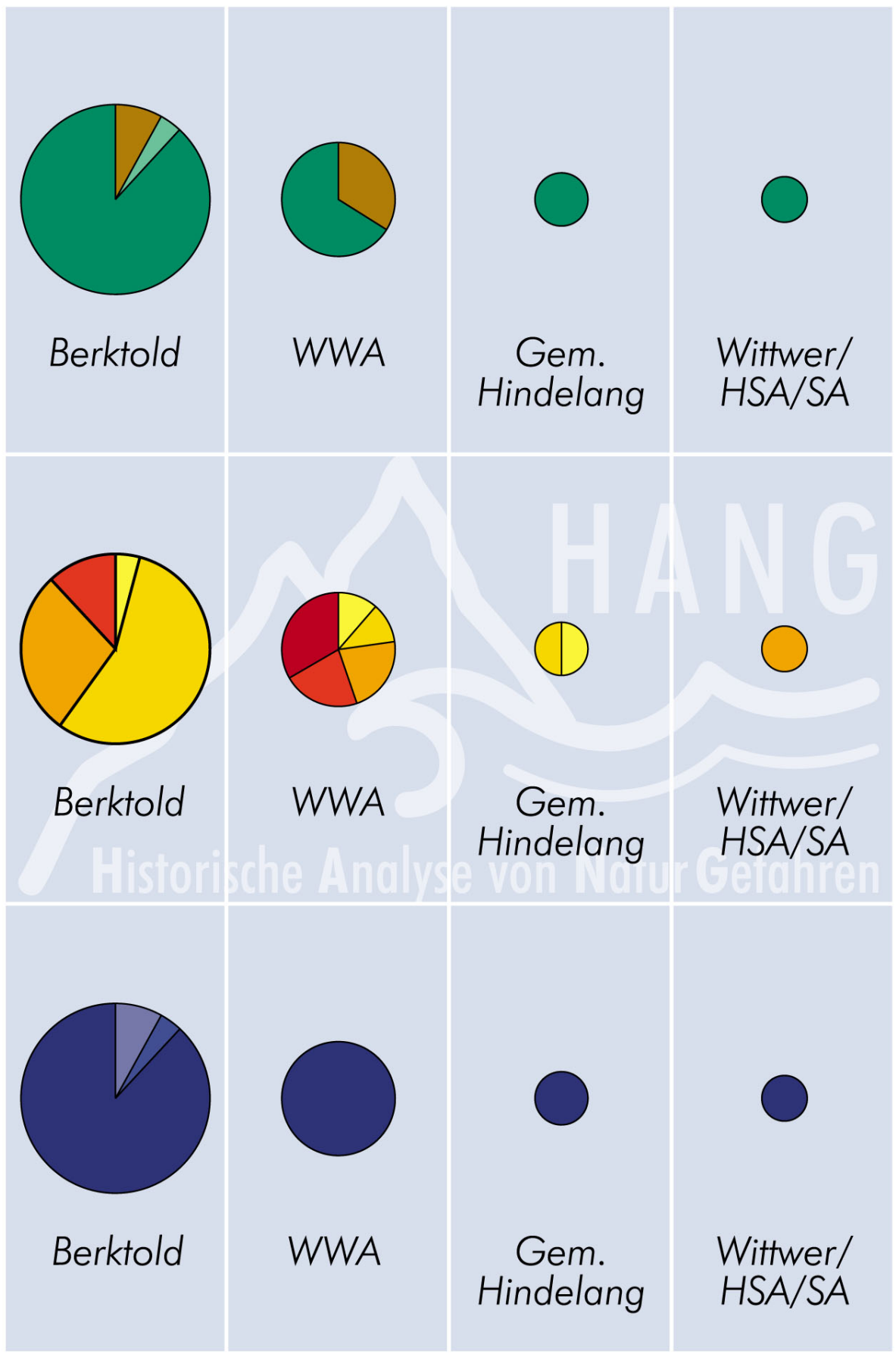

Fig. 5. Avalanches: authenticity, quality, age of references (key: see Fig. 3).

floods, debris-flows or avalanches are concerned, and regardless of the type of source analysed (e.g. just one chronicle or only religious scripts). The findings of the HANG project contribute to the evaluation of natural risks in a clearly defined area in the Alps.

While written sources from the last few centuries are relatively common, medieval documents are very rare in local archives. State archives in Germany often store documents from clerical archives dissolved between 1803 and 1806 un- der Napoleonic influence. They also keep governmental documents like orders, letters and measures taken in case of a catastrophical event. But to evaluate the local fluvial dynamics for example, even data from only the 18th to 20th century, which can be found in most municipal archives, are valuable enough to provide a sufficient basis for hazard zone mapping.

For a systematic assessment of all informative documents the archives relevant for the research areas (in the case of HANG the areas around Hindelang and the Tegernsee 


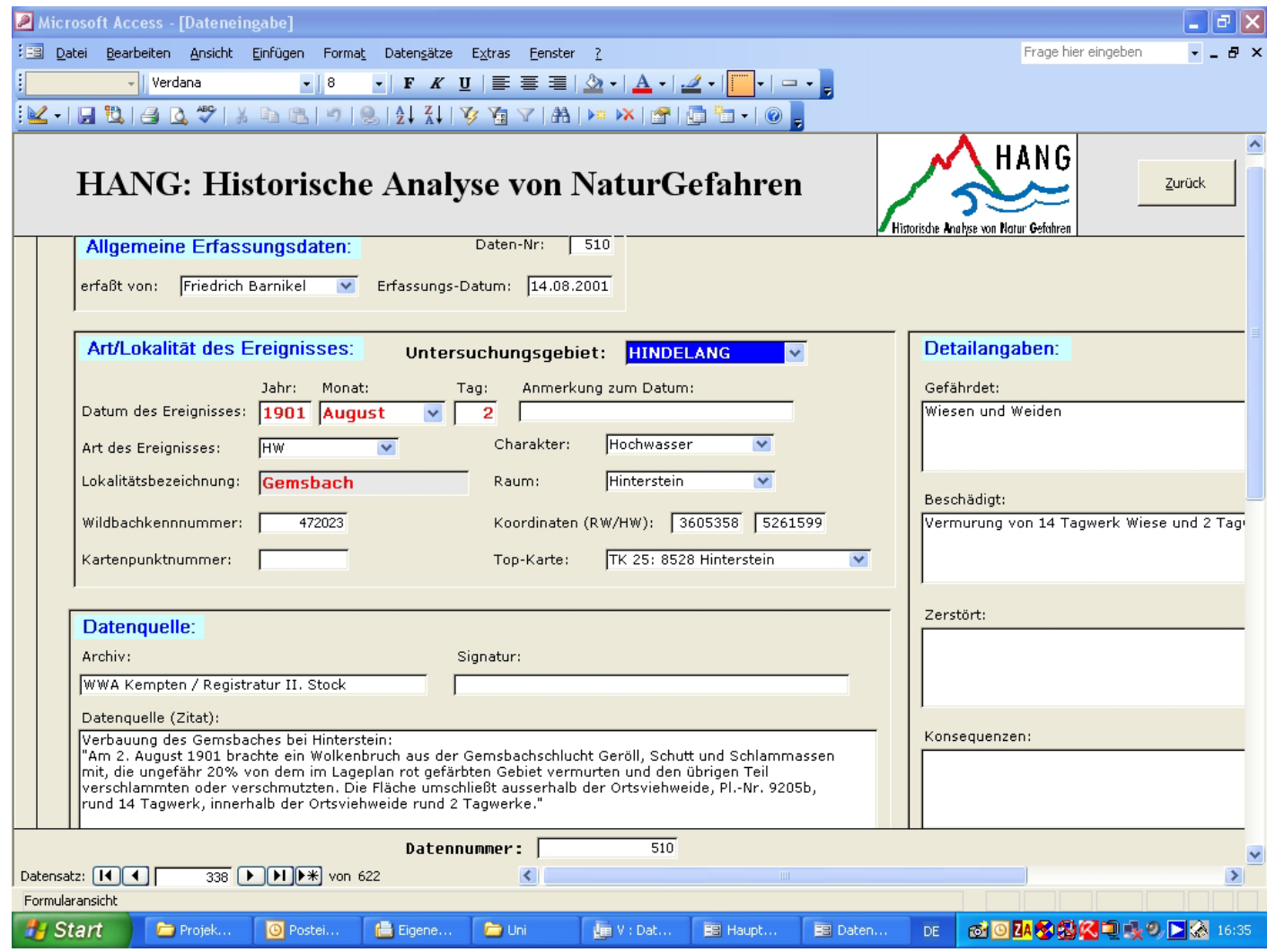

Fig. 6. HANG data base (HDB) sheet 510 of the 1901 event of the Gemsbach.

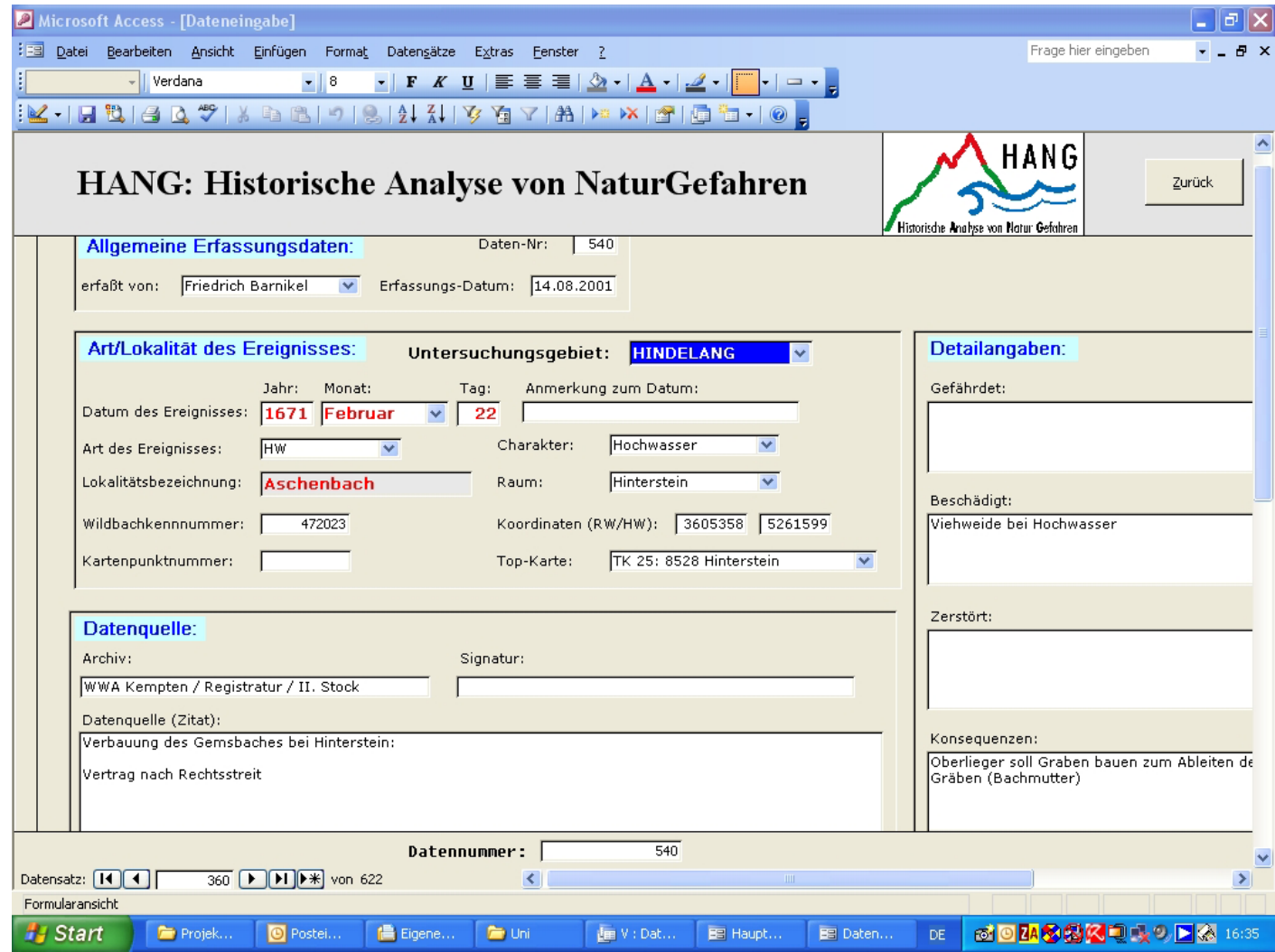

Fig. 7. HDB sheet 540 of the 1671 event of the Aschenbach. 


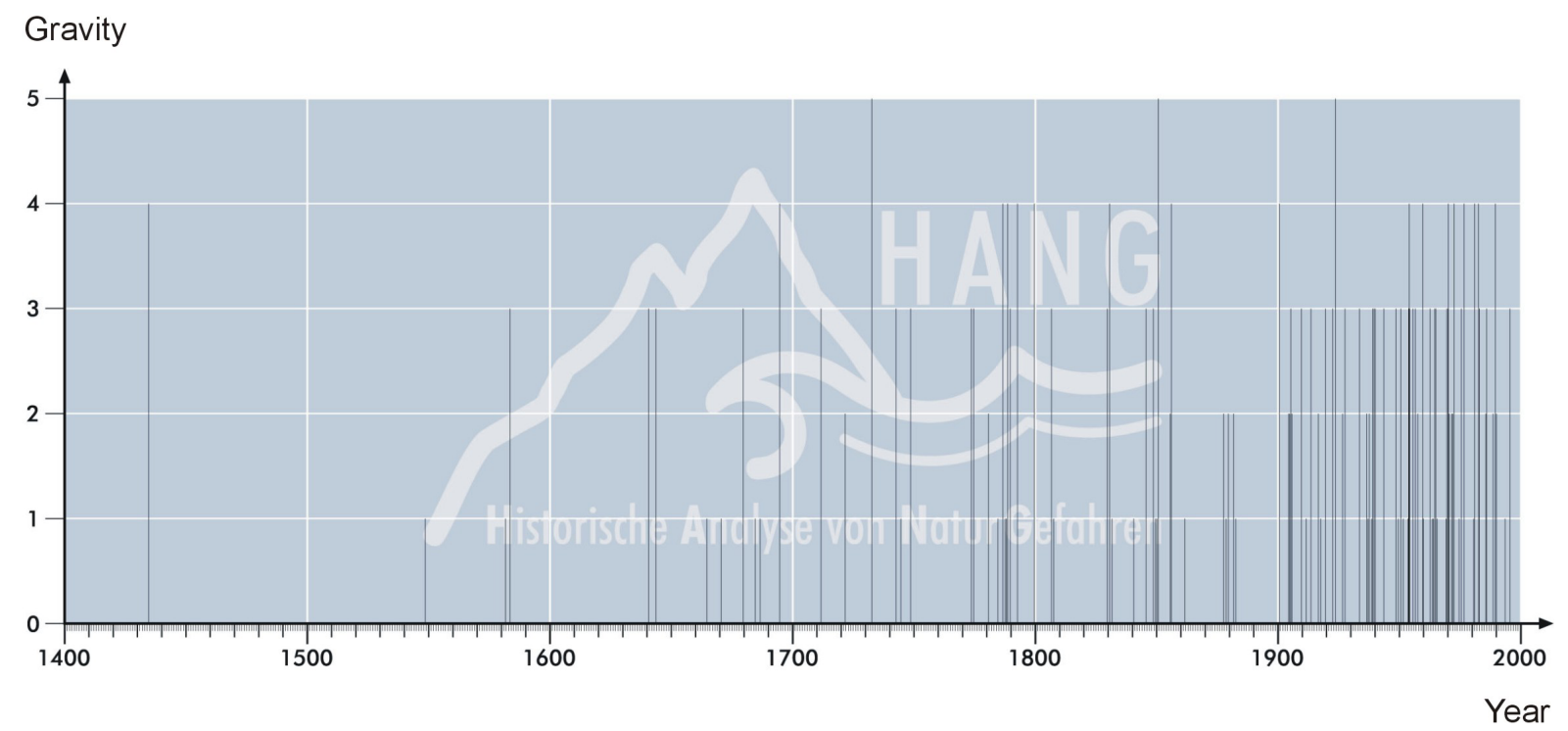

Fig. 8. Chronological distribution of flood events with respect of their severity (Hindelang area).

Valley) have to be listed first. Of special importance are the archives of the state agencies (State Agency for Water Management/Munich, Geological Survey/Munich, regional Agencies for Water management in Kempten and Rosenheim) and municipal archives. Other archives include church archives and private collections (newspaper archives, chronicles etc., Fig. 1) The access to most archives comprises no problems, some archives, especially private ones, on the other hand may remain inaccessible. Since many archives lack a modern and logical structure numerous stacks of documents have to be worked through. Some of the documents are almost illegible, others heavily damaged. Maps, illustrations and photographs are copied and stored in electronic data files. The data is then structured (place, time, kind of event etc.) and listed in a specifically designed data sheet (cf. Figs. 6 and 7). Eventually the data is included in a data bank which allows a systematic search for information.

As a result, all the references for events combined make up one event which can be graphically illustrated in a map of a hazardous event and all areas affected by it. At the same time the events are classified with regard to their age, source and source quality. After the multiple entries have been deleted the events are classified after their gravity or severity, this step is especially important for the rivers and mountain torrents. At the end of the analysing process the different rivers and torrents are classified after their hazardous potential as is the case with endangered slopes.

Eventually they are divided in three groups, flood events, geomorphic/geological events and avalanches. Geomorphic/geological events include rock falls, rock slides, debrisflows etc. Many of the geomorphic hazards only affect small areas far away from any settlement. On top of that quite often one can hardly pinpoint the factual date of the event. Many events can only be recognized some time after they actually happened, so that there is only a terminus ante quem, which makes the case different from the flood events, which are usually well dated (Fig. 8). The fact that they often appear in uninhabited regions means that there are far less written documents about these events as there are for flood events. Similar caveats apply to avalanches, they only make a small part of the total number of events.

In total, a number of 882 references were found in both study areas, 410 for Hindelang alone. The bulk of events from the Hindelang area are flood events (251 references), much less are of geomorphic/geological nature (debris flows and landslides, 100 references), quite a few snow avalanches have also been recorded (59 references). Naturally most of the damage occurs with floods, since the villages usually centre around bridges or fords crossing the rivers, and are therefore vulnerable. Geomorphic/geological events and avalanches usually tend to happen in areas with less inhabitants and thus are not always considered worth reporting. About two thirds of all references for hazardous flood incidents (177 out of 251) have been found for the 20th century. Since the foundation of state run offices for water management in Bavarian provinces in the latter half of the 19th century the registration of natural disasters connected with rivers has dramatically improved. Consequently, the fact that we recorded more findings from the more recent centuries compared to earlier times not necessarily means that there are in fact more hazardous events nowadays, it has to be understood as a sign of better registration owing to the administration and the greater interest of people in natural hazards due to growing awareness. Additionally, more people have settled in endangered areas and more goods are threatened. 70 references date back to the first half of the 20th century, where a lot of documents have been lost due to World War II. Most documents about geomorphic/geological events and avalanches came from the 20th century, only very few references are older. 
Very desirable are documents from different archives, parallelly shedding light on the same event. Unfortunately more than $80 \%$ of the events have only been mentioned in one single document. Only younger events have found entry in more than one archive and are, consequently, better substantiated. As a consequence, as many archives as possible need scrutinizing for singular references to hazardous events. The older documents are nevertheless of special importance since they tell us something about the continuity of natural disasters in the area.

As to the quality of the data, more than $50 \%$ of all data for Hindelang were of at least satisfying degree. That means that a concrete date for an event was given and in addition more details regarding origin, cause, damages and/or consequences. In about $15 \%$ of all references only a date was given with the remark that an event had taken place, but no further explanation or clarification were given. Still, even these simple remarks, especially when coming from older documents, give evidence of the activity of a certain river. Nevertheless, it must be stated that in several cases the documentary evidence for an event is comparably slight, these dates have to be treated with caution.

Since, as has been mentioned above, many archives lack a modern and clearly structured registration, quite a lot of files have to be worked through for references which lead to documents describing hazardous events. Findings are listed in a data bank and visualized in maps of natural hazards in the area (Map 1). The results of this meticulous analysis lead to a more profound knowledge about the regional differentiation of hydrological and geomorphic dynamics in the Alps. They prove especially useful for the development of hazard zone maps. Since most of the data collected for hazard zoning will show a more recent picture of the area, and people are not able to remember past events well, only historical written documents provide the basis for a truly long series of hazardous events necessary for probability analyses for future events. The Hindelang area in the Allgäu part of the Bavarian Alps may serve as an example, since a traditional hazard zone mapping has been carried out for purely scientific reasons in 1997 and a thorough historical analysis made between 2000 and 2003 adds significantly to the knowledge about the local hazardous potential.

\section{The research area}

\subsection{Overview}

The Hindelang area is situated in the Allgäu part of the Bavarian Alps (Map 2). It has a size of about $137 \mathrm{~km}^{2}$ and includes the villages of Hindelang, Bad Oberdorf, Vorderhindelang and Hinterstein with a total of 4840 inhabitants. The study area Hindelang consists of the valley of the mountain torrent River Ostrach, which has its source in the Allgäuer Alpen, a mountain range at the German-Austrian border. The catchment area of the Ostrach has elevations ranging from $780 \mathrm{~m}$ a.s.l. (Ostrach near Vorderhindelang) to $2594 \mathrm{~m}$ a.s.1.
(Hochvogel), was glaciated in the Pleistocene and is characterised by large grazing areas between dense mountain forests. The geology is very complex. The southern part of the area belongs to the northern limestone Alps (with frequent debris flows events), whereas the lower northern part is characterised by the Flysch-zone, which is susceptible to slide events. The steep slopes all through the Ostrach valley support several small torrents tributary to the Ostrach. One of them is the Gemsbach, which has a catchment of about one square kilometre (Map 2). Especially in winter snow avalanches are regular for the southern part of the valley with elevations higher than $1400 \mathrm{~m}$ a.s.l. The mean annual precipitation rate is around $1630 \mathrm{~mm}$ (Hindelang station) with the highest monthly rates between June and August (more than $200 \mathrm{~mm}$ each month) as is typical for stations in the Bavarian Alps. The mean annual temperature is around $7^{\circ} \mathrm{C}$, ranging from $-2^{\circ}$ in January to $16^{\circ}$ in July. Hindelang, the largest community in the Ostrach valley, was first mentioned in a document in 1150, but the area had been inhabited for at least three centuries at that time. It became an independent parish in 1435. The intensification of farming activities in the Allgäu region from the 17th century onwards led to an expansion of the settlements around Hindelang into endangered parts of the valley, thereby increasing the vulnerability of sites. Today, Hindelang is a favourite tourist spot both in summer and winter.

\subsection{Hazard zoning for the Gemsbach}

The authors of the scientific hazard zoning for the Gemsbach area, Geist (1997) ${ }^{1}$ and Maier (1997) ${ }^{2}$, used methods developed by French and Austrian authorities (confer Antoine, $1991^{3}$ or WLV, 1994). The analysis of historical information sources and other documents is considered vital in Austria, as Geist $(1997)^{1}$ points out. Other steps to gather information for the hazard zone mapping included questioning the locals, mapping by way of analysing aerial photographs and the estimation of the possible extent and severity of an event. Additionally, inspections in the field contributed to the amount of information gathered.

One of the major problems arising when working at hazard zone maps is, understandably, the time factor. While most other tasks for hazard zoning can be met within reasonable spans of time, usually there is not enough time (and funding) for a thorough historical analysis. Maier (1997: 62) ${ }^{2}$ states: "Unfortunately references for pre-1900 events were very rare

\footnotetext{
${ }^{1}$ Geist, T.: Gefahrenzonenplanung im Alpenraum: Bestandsaufnahme im deutschsprachigen Alpenraum und Anwendung eines Konzepts am Beispiel einer bayerischen Gemeinde, unpublished thesis, 1997.

${ }^{2}$ Maier, M.: Gefahrenzonenplanung in den Alpen - Bestandsaufnahme im französischsprachigen Alpenraum und Anwendung eines Konzepts am Beispiel einer bayerischen Gemeinde, unpublished thesis, 1997.

${ }^{3}$ Antoine, P.: Cartographie du Risque Mouvement de Versant, L'expérience francaise, Paper for a presentation in Geneve unpublished, 1991.
} 


\section{Historical Map of Natural Hazards}

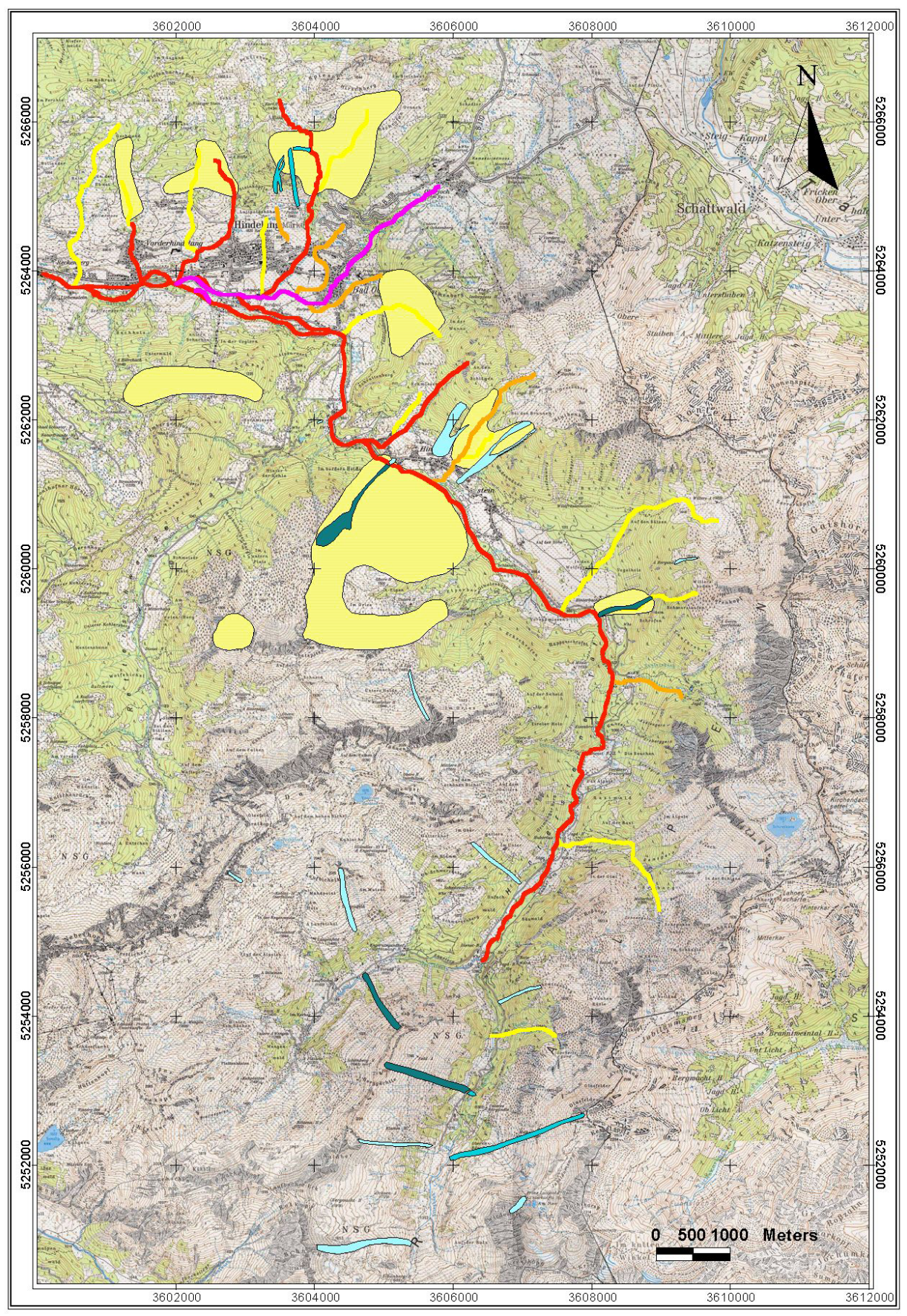

Extremely active river
$\begin{aligned} & \text { Alghly active river } \\ & \text { Avalanches }\end{aligned}$
$\begin{array}{ll}\text { Active river } & \text { Class I: yearly occurence } \\ \text { Rarely active river } & \text { Class II: occurence at least once in ten years }\end{array}$
$\begin{array}{ll}\text { Class III: occurence less than once in ten years }\end{array}$

Map 1. Map of natural hazards established from historical documents. (Hindelang area) 


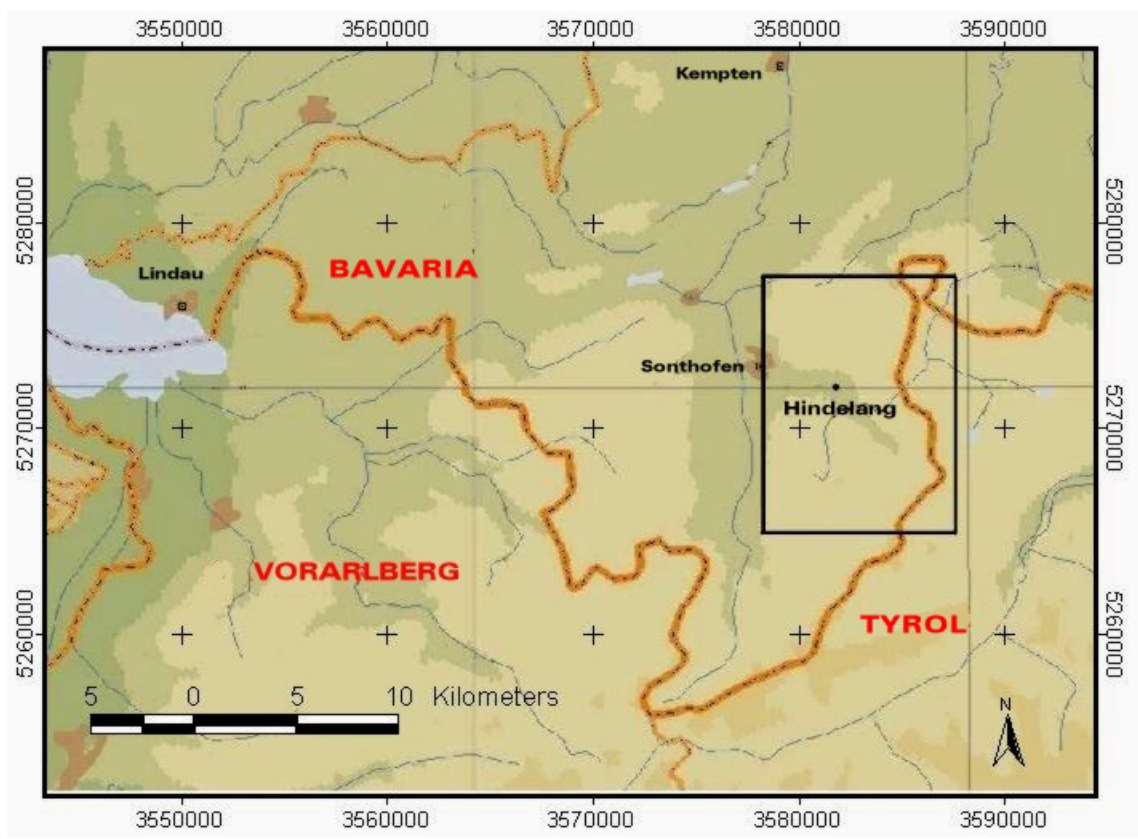

Map 2. Study area Hindelang of the HANG project.

[in the archive of the Municipality of Hindelang]." Yet, quite the contrary is the case. The Hindelang archive, when scrutinized for the HANG project, yielded an impressive number of documents dating back to the late middle ages. Most of them are just hardly decipherable. One needs, in most cases, a historian to read and evaluate the documents. Events earlier than 1900 were found by Geist and Maier in a list of flood events printed in a special issue of the local paper to commemorate the major flood mitigation works in Bad Oberdorf near Hindelang in 1978. Maier calls this list a "very good documentation". In fact, it is a mere list and no further information on causes of the floods, spatial distribution, extent, duration, damages and other necessary aspects is given.

Maier and Geist are not to blame for shortcomings of traditional ways of hazard zone mapping. But historical data collected and analysed by the HANG project shows floodprone areas around the Gemsbach differing greatly in size and location from the one shown in the hazard zone maps they drew for the area. The inclusion of all data available for the Gemsbach area (15 events between 1671 and 1960 collected from four different archives - Figs. 6 and 7) leads to a completely new picture of the regional hazardous activity and demands a complete re-structuring of the traditional way of hazard zone mapping. Every half-century of old documents, roughly spoken, brought a new dimension of the area endangered by floods. Especially the heavy floods of 1901 and 1851 contribute immensely to the extent of vulnerability in Hinterstein. A survey among the local population with questions on the largest flood known did not lead to reliable results. Most people did not remember events older than 30 to 40 years properly and they tended to mix up the correct dates. Events further back than 100 years, like the ones in 1901 and 1851, can only be registered by a historical analysis.
3.3 Flood analysis for the Gemsbach with historical documents

The most recent of the grave events, apart from a flood in 1960 , was the flood of 1954, still remembered by many older locals as the "most severe of all floods" in the area (Map 3). This event hit almost all torrents in the Tegernsee valley area with partially grave floodings (see Barnikel, 2004), but was much lighter in the Hindelang area, where it mainly affected the torrents in the Hinterstein Valley, the valley of the river Ostrach. The area flooded by the Gemsbach can be seen in Map 3. As a consequence sediment traps were built in the middle and lower part of the torrent Gemsbach to prevent future flooding of the adjoining grassland and the houses near the Ostrach. The Bavarian State invested about EUR 170000 for hazard mitigation in the years after the 1954 event.

Some twenty years prior to that event an employee of the Local Hydrological Office (LHO) in Kempten had drawn a map of the Gemsbach. In that map he included an area possibly endangered by future floods after some undisclosed research he had done the years before. He feared a flood which would threaten the middle part of Hinterstein, by far the largest of the three village parts (Map 4). The torrent might leave its bed in a slight curve after a steep ravine-like section. In the field one can clearly see a dry watercourse leading away from the torrent towards the middle village, a good example for a "silent witness" after Aulitzky 1992. There must have been water flowing down the slope towards the middle village at some stage in the past, the documents, however, do not yield any evidence for such an event.

Between 1954 and 1901 seven flood events (1939, 1939, 1924, 1923, 1920, 1918, 1910) were found by the HANG project, none of them included in the hazard zone mapping by Geist $(1997)^{1}$ or Maier $(1997)^{2}$. 


\section{Municipality of Hindelang}
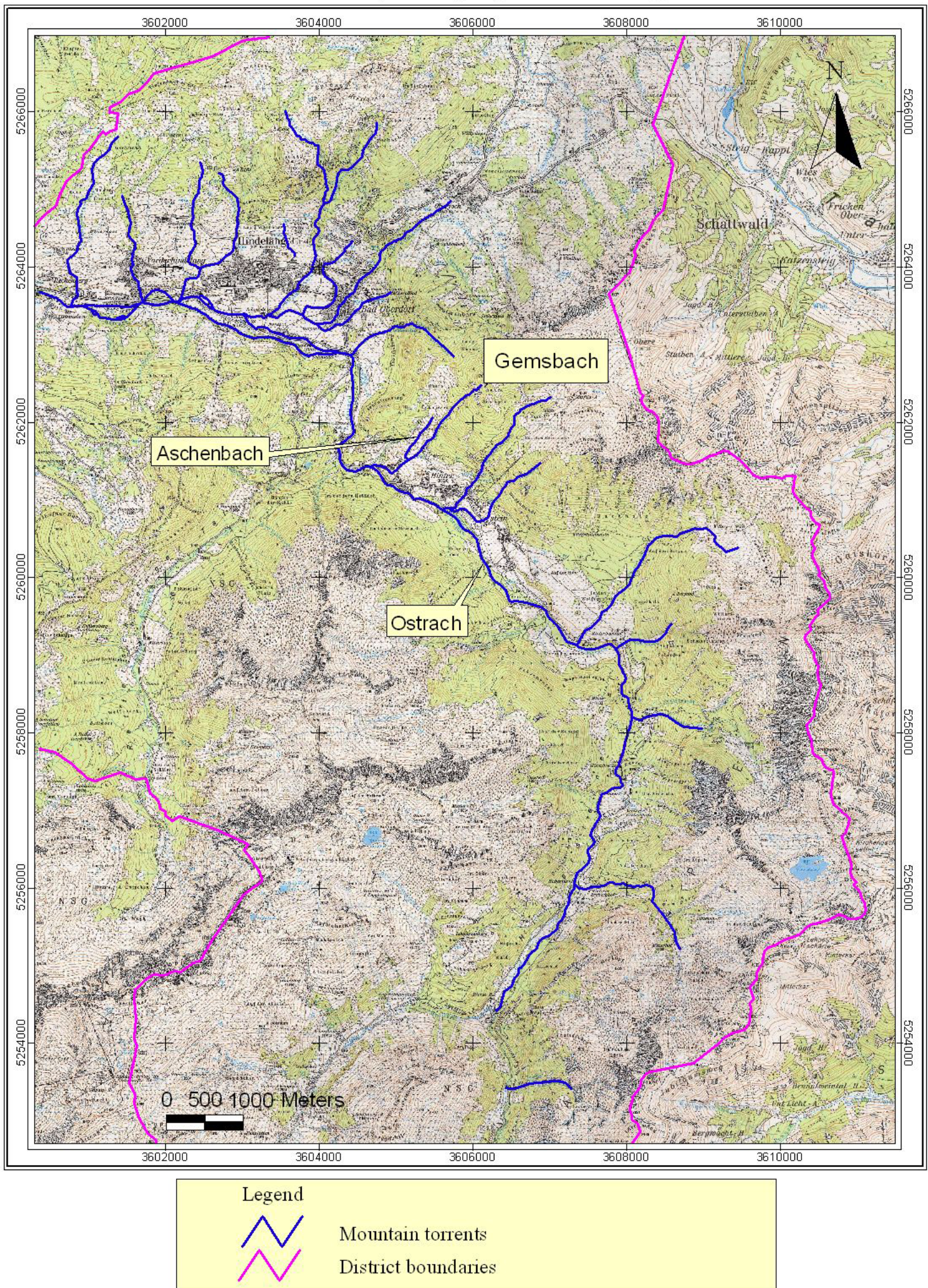

Map 3. Map of the Municipality of Hindelang (for all following maps: map made by Friedrich Barnikel, reprinted with permission of the Bavarian Topographic Survey/Munich number 1949/04 on basis of the TOP 25, Sheet 8528). 
1954

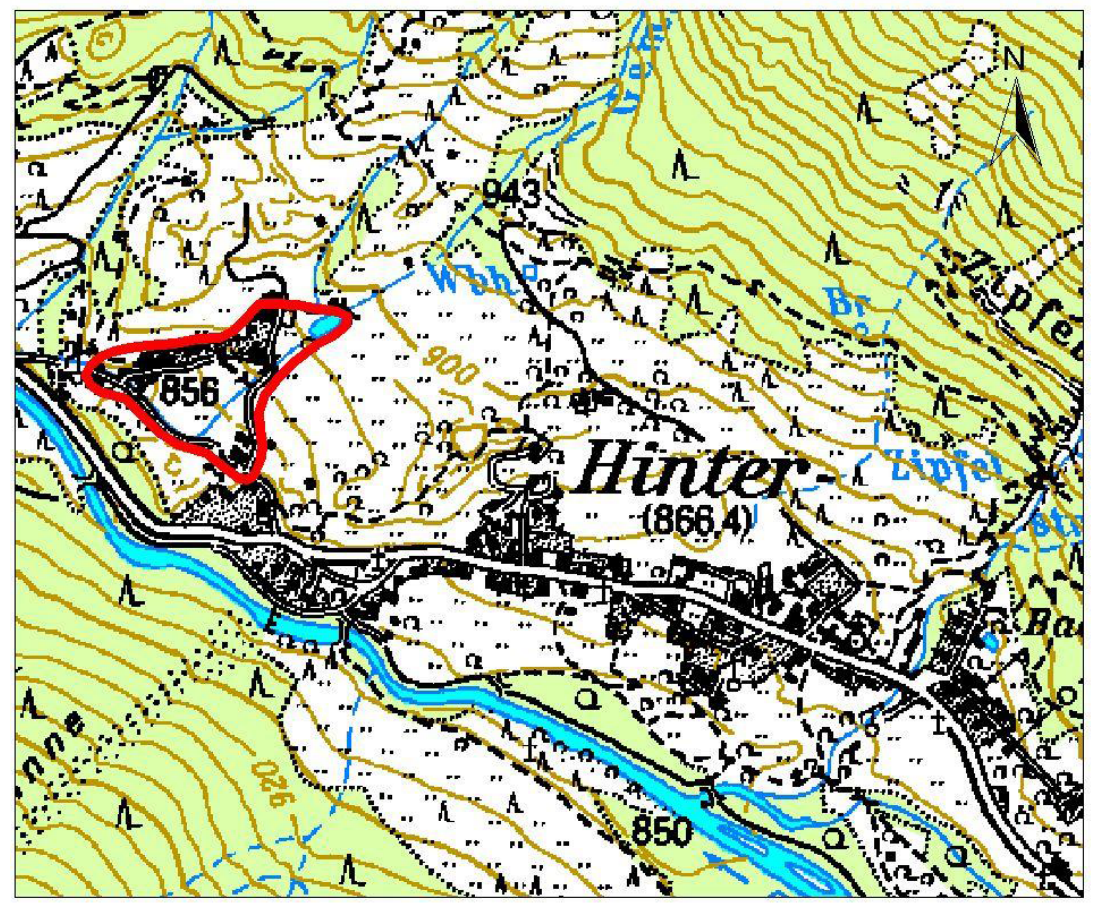

Map 4. Area supposed to be endangered by future floods after the hazard zone maps by Geist (1997) ${ }^{1}$ and Maier (1997) ${ }^{2}$.

\section{5}

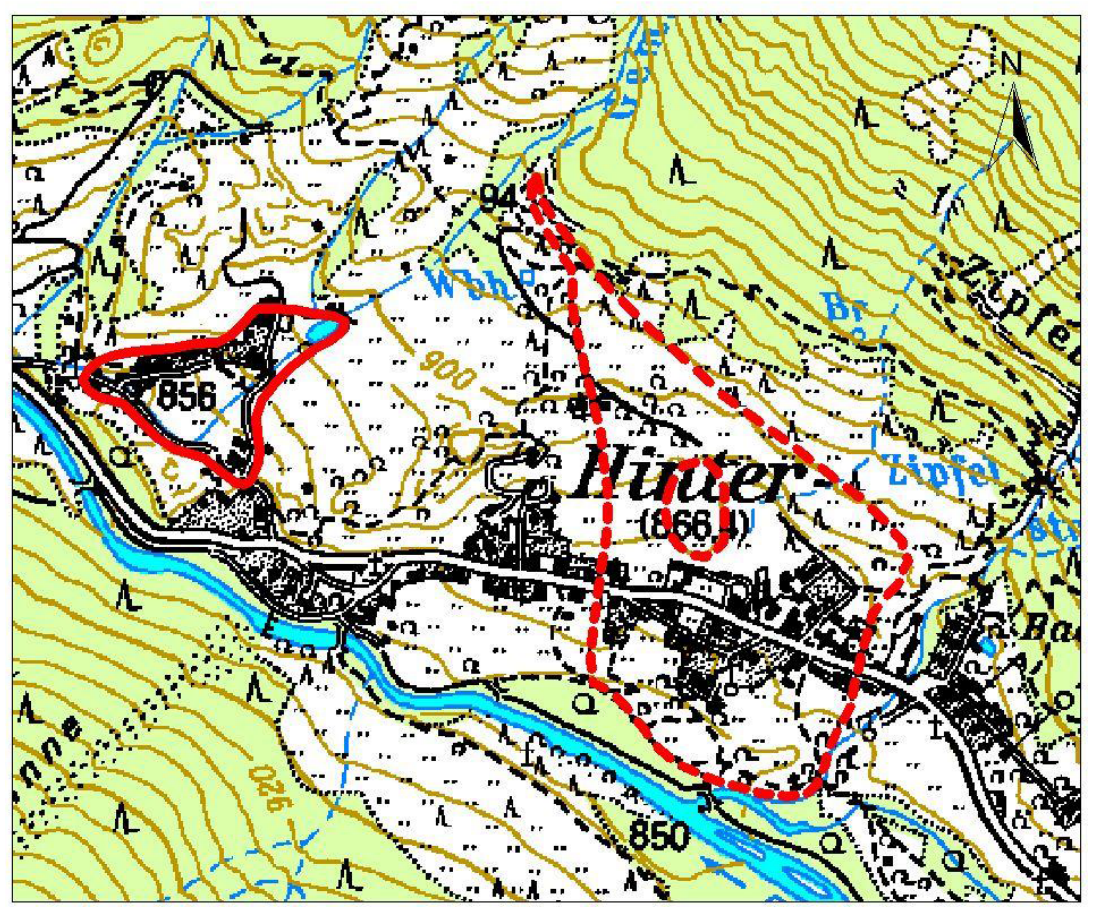

Map 5. Area supposed to be endangered by future floods after a map of the Local Hydrological Office in Kempten from the year 1935 (plus area of Map 4). 
1901

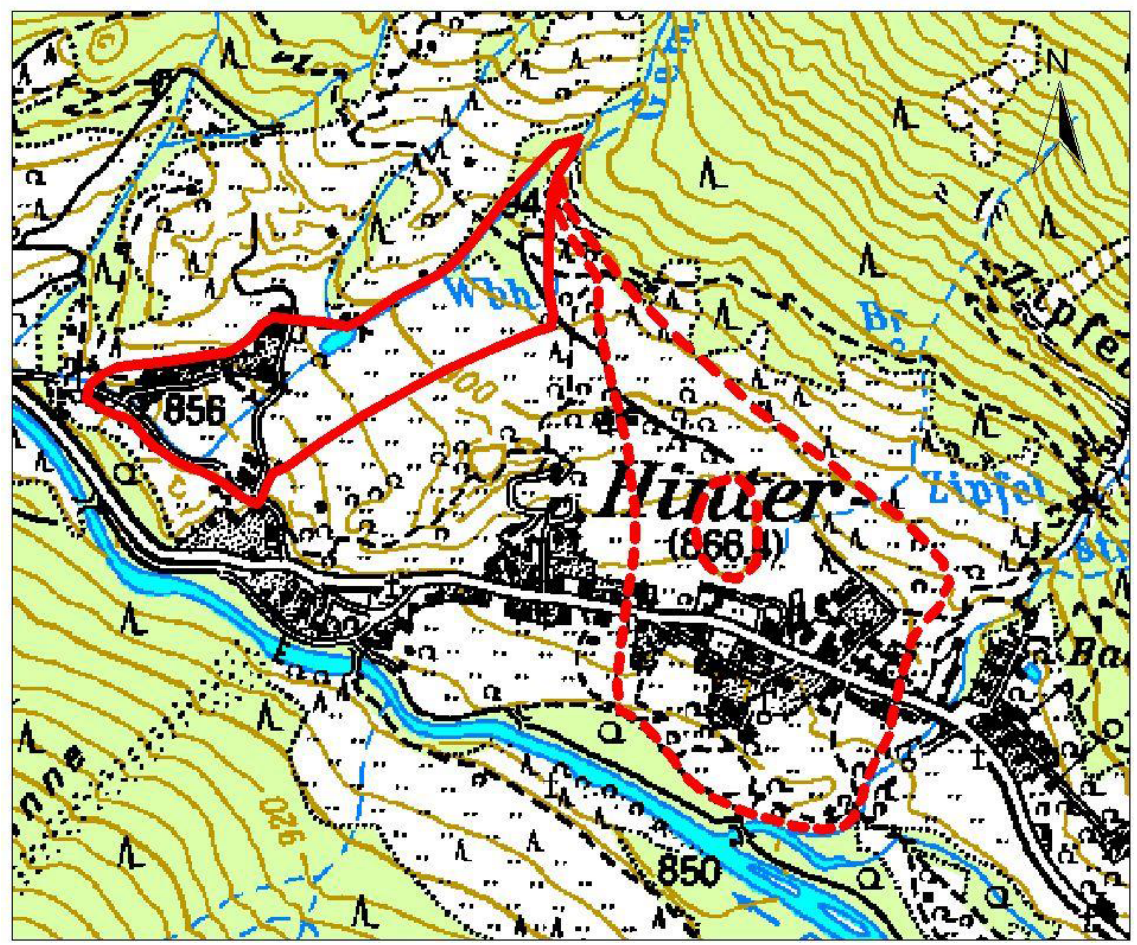

Map 6. Area flooded by the 1901 event (plus areas of Maps 4 and 5).

1851

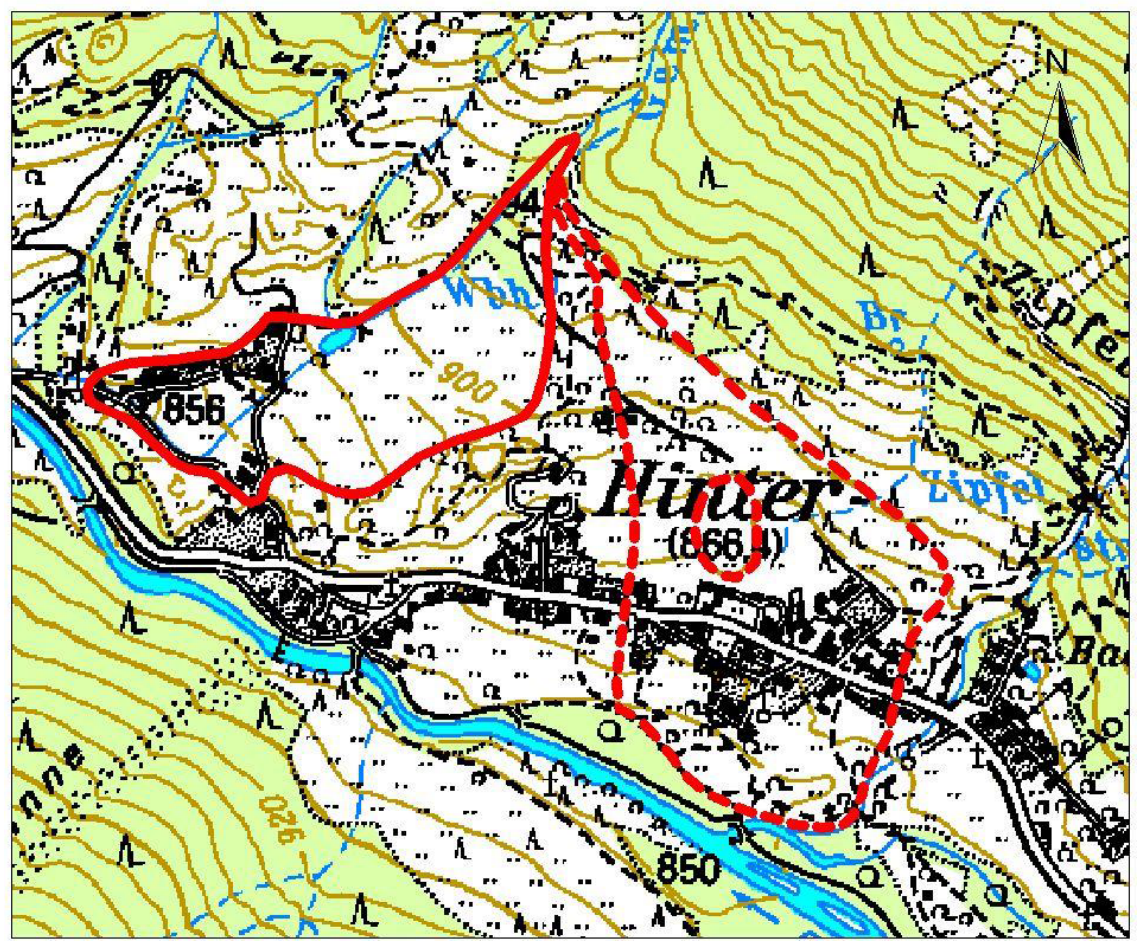

Map 7. Area flooded by the 1851 event (plus areas of Maps 4-6). 


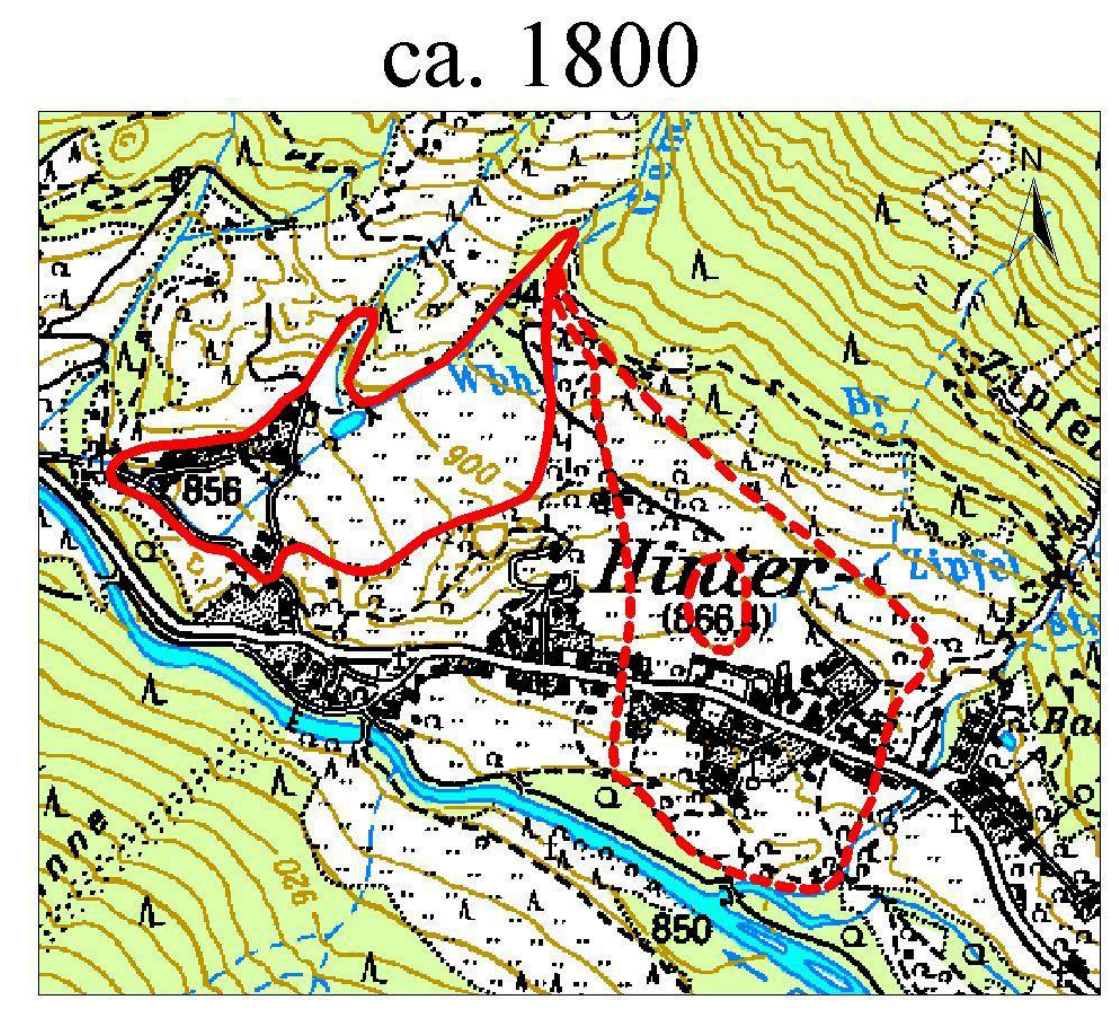

Map 8. Area flooded by the Aschenbach in events prior to 1800 (plus areas of Maps 4-7).

Bridges were damaged, roads destroyed and fields and pastures filled with debris. Most references were found in the archive of the LHO in Kempten, but some references were made in documents found in the municipal archive in Hindelang.

The flood of August 1901 (Fig. 1) in the Gemsbach area was part of a series of flood events which hit large parts of the Bavarian Alps. The map of 1935 drawn by the employee of the LHO in Kempten clearly outlines the area flooded. It is no surprise that nowadays no local can remember this event, but the documents show the extent of the flood and its severity. This event was graver than the one in 1954, houses were damaged, bridges destroyed and the rivers, notably the Gemsbach carried debris into the adjoining fields and pastures (Map 5).

Exactly 50 years ago, on 2 August 1851, another flood event had taken part in the Gemsbach area. Judging from the historical documents alone, which were found in the State Archive in Augsburg, and the map of 1935, this event was the gravest in history for the Gemsbach. Compared with the flood of 1901 even larger parts of the village pasture were flooded, the question how far houses and the infrastructure were hit remains unsolved (Map 6). If compared to the area deemed endangered by Geist $(1997)^{1}$ or Maier $(1997)^{2}$ (Map 3) one sees that the real extent of the endangered area, judging from flood events in the past, is considerably larger. The sediment traps and other measures taken in the lower part of the torrent after the 1954 event can be neglected in the case of a river outbreak in the middle part, where they would be of no use. The ravine part had been blocked in the years 1922/23, but, as Geist (1997) ${ }^{1}$ points out, these constructions have been almost totally destroyed in the meanwhile and would be of no help in the case of a new event.

A tributary torrent, the Aschenbach, flooded some pastures prior to 1800 in the 1775, 1774 and 1671 events (Fig. 2). Compared with the destructivity of floods by the Gemsbach the Aschenbach only inflicted minor damage to the area. But about ten years ago a local family built a new house in the area where the Aschenbach, two centuries ago, used to flood the meadows. If ones goes back in time that far, in this case based on documents by the LHO, one can come to the conclusion that the area deemed endangered by floods must be calculated even larger than shown in Map 6. If all events are included an area known to have been hit by floods would enclose the Aschenbach part of the catchment as well (Map 7). Since the vegetation of the area and other geographic features have not changed much over the past 200 years and because the structures put up to block the torrent have mostly been badly damaged or are useless, the probability is high that rainfall-cum-flood events as in 1851 might happen again and inflict similar damage to the population. When one takes into consideration the fact that more values have been accumulated in the village and that more houses now exist (compared to 1800), the damage would be even graver. 


\section{Discussion}

Notwithstanding their natural limitations, as mentioned above, historical documents can enormously add to the knowledge about local hydrological dynamics. A thorough analysis of historical documents has to get more attention by officials and scientists alike when attempting hazard zoning. The amount of time which has to be invested is considerable, but the results are very valuable. Future assessments could start with a historical analysis of larger areas, not singular catchments. Such an approach would minimize costs and maximize the output. At the moment the successor of the HANG project, HANG2/HAWAS deals with all documents of the Local Hydrological Offices in the Bavarian Alps. A second step will then be further research in local archives and state archives. So far it can be concluded that future attempts to hazard zone mapping should get adequate financing to be able to provide a wider basis of knowledge and a larger set of data.

On the other hand, the historical data has to be complemented by proxy data in the field. Especially the Gemsbach area is promising in that respect. The part of the torrent, where the silent witness of the watercourse towards the middle village has been found, needs further research. Drilling in that area should yield different layers of sediment and consequently lead to a more profound knowledge of fluvial dynamics in addition to the long list of written documents relevant for the area.

Future projects should, therefore, not only include classical scientific data, but also historical data, data from remote sensing and data from inspection in the field. A next step should be the creation of networks of data. For the Bavarian Alps the System IAN (Information System of Alpine Hazards) is already in use and new systems like DOMODIS (Documentation of Mountain Disasters - Hübl et al., 2002) will be created, which should include data from all Alpine countries in Europe. Interdisciplinarity and internationality will be the key to a more successful and sustainable hazard mitigation in the Alps.

Acknowledgement. The author wants to thank the Bavarian State Ministry of Development and Environment for funding the project.

Edited by: J. M. Vilaplana

Reviewed by: one referee

\section{References}

Ammann, W., Buser, O., and Vollenwyder U.: Lawinen (Basel), 1997.

Aulitzky, H.: Die Sprache der "Stummen Zeugen", Internationales Symposion Interpraevent - Schutz des Lebensraumes vor Hochwasser, Muren und Hangbewegungen, 6, 139-174, 1992.

Aulitzky, H.: Richtlinienvorschlag für die Erstellung von WildbachGefahrenzonenplänen, Internationales Symposion Interpraevent - Schutz des Lebensraumes vor Hochwasser, Muren, Lawinen und Hangbewegungen, 4, 177-186, 1996.
Baron, W. R.: Historical climate records from the northeastern United States, 1640 to 1900, in: Climate Since A.D. 1500, edited by: Bradley, R. S. and Jones, P. D., 74-91, 1995.

Barnikel, F.: Analyse von Naturgefahren im Alpenraum anhand historischer Quellen am Beispiel der Untersuchungsgebiete Hindelang und Tegernseer Tal, Bayern, Göttinger Geographische Abhandlungen, 111, 209 p., 2004.

Barnikel, F. and Becht M.: A historical analysis of hazardous events in the Alps - the case of Hindelang (Bavaria, Germany), Natural Hazards and Earth System Sciences, 3, 625-635, 2003,

SRef-ID: 1684-9981/nhess/2003-3-625.

Barnikel, F. and Copien C.: Lawinenereignisse in alten Dokumenten und ihre Bedeutung für die aktuellen Lawinenkataster., Mitteilungen der Geographischen Gesellschaft München, Band 87, in print, 2004.

Benito, G. and Thorndycraft, V.: Systematic, Palaeoflood and Historical Data for the Improvement of Flood Risk Estimation, 2004.

Deutsch, M. and Pörtge, K.-H.: Hochwasserereignisse in Thüringen, Schriftenreihe der Thüringer Landesanstalt für Umwelt und Geologie, 63, 2002.

Fliri, F.: Naturchronik von Tirol, Innsbruck, 1998.

Gees, A.: Analyse historischer und seltener Hochwasser in der Schweiz, Geographica Bernensia, G 53, 1997.

Glade, T., Albini, P., and Francés, F.: The Use of Historical Data in Natural Hazard Assessments, Advances in Natural and Technological Hazards Research, 17, 2001.

Glaser, R.: Klimageschichte Mitteleuropas, Darmstadt, 2001.

Hübl, J., Kienholz, H., Loipersberger, A.: DOMODIS - Documentation of Mountain Disasters, Internationale Forschungsgesellschaft Interpraevent, Schriftenreihe 1, Handbuch 1, 2002.

Kienholz, H.: Hazard maps: decisive parameters and criteria for definition of intensity degree, Internationales Symposion Interpraevent - Schutz des Lebensraumes vor Hochwasser, Muren, Lawinen und Hangbewegungen Volume 3, 47-58, 1996.

Martín-Vide, J. and Barriendos M.: The use of rogation ceremony records in climatic reconstruction: A case study from Catalonia (Spain), Climatic Change, 30, 201-221, 1995.

Naulet, R., Lang, M., Coeur, D., and Gigon, C.: Collaboration between historians and hydrologists on the Ardeche River (France), in: The Use of Historical Data in Natural Hazard Assessments, edited by: Glade, T., Albini, P., and Francés, F., Advances in Natural and Technological Hazards Research, 17, 113-129, 2001.

Pfister, C.: Wetternachhersage, 500 Jahre Klimavariationen und Naturkatastrophen (Bern), 1999.

Pfister, C. and Hächler, S.: Überschwemmungskatastrophen im Schweizer Alpenraum seit dem Spätmittelalter, Würzburger Geographische Arbeiten, 80, 127-148, 1991.

Stedinger, J. R. and Cohn, T. A.: Flood frequency analysis with historical and paleoflood information, Water Resources Research, 22/5, 785-793, 1986.

Wagner, K. and Suda, M.: Natural hazards in the perspective of the public - A big black box, Internationales Symposion Interpraevent - Schutz des Lebensraumes vor Hochwasser, Muren, Lawinen und Hangbewegungen, Volume 4/IX, 285-296, 2004.

Wang, P. and Zhang, D.: An introduction to some historical governmental weather records of China, Bulletin of the American Meteorological Society, 69/7, 753-758, 1988.

WLV: Gefahrenzonenplan Viehhofen, GenBMLF ZI:52.243/52VC8a/93, 1994. 